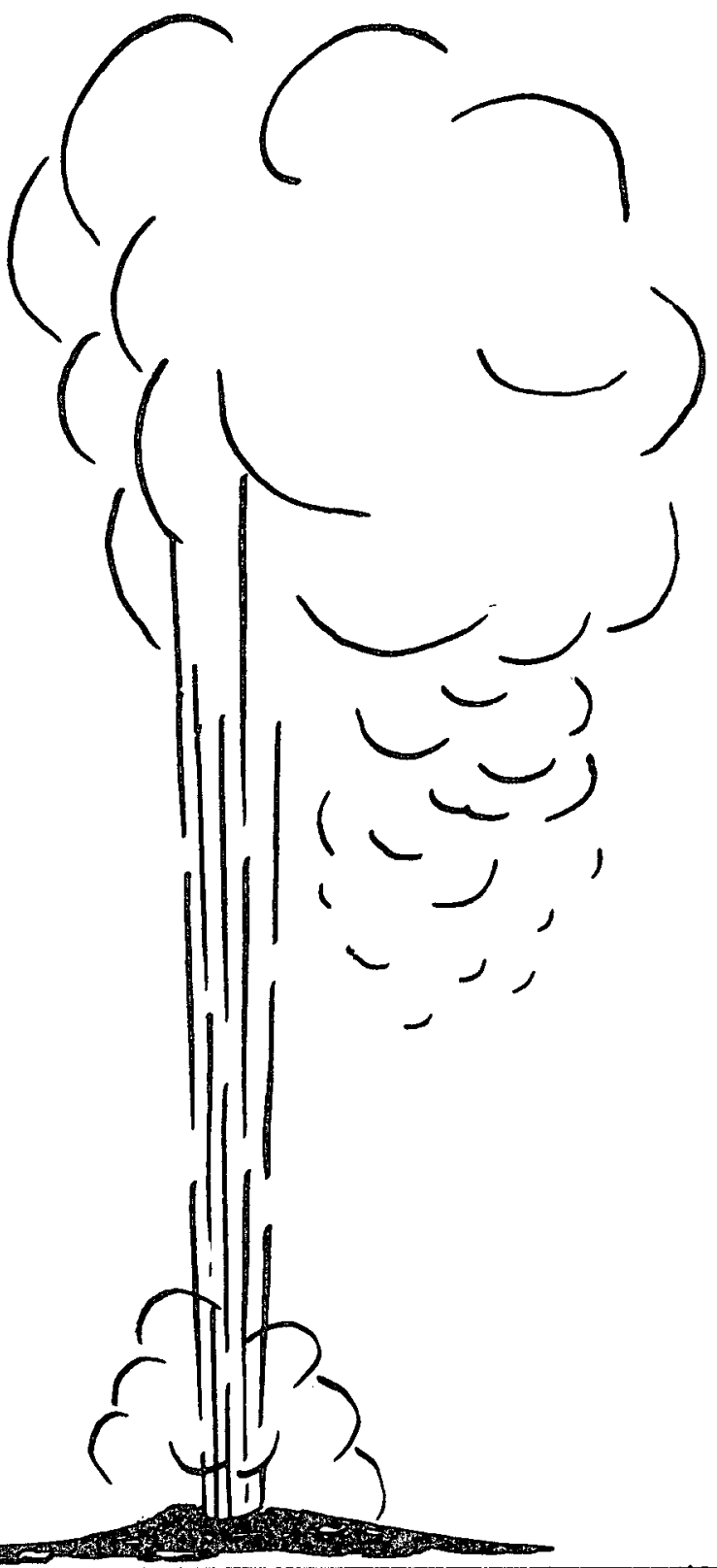

Engineering \& Economic Studies

for Direct Application of Geothermal Energy

\title{
ETHANOL PRODUCTION FOR AUTOMOTIVE FUEL USAGE
}

Quarterly Report, 2 July - 30 September 1979

By

S.C. May

R.A. Stenzel

M.C. Weekes

J. $\mathrm{Yu}$

Date Issued - 31 October 1979

Work Performed Under

Contract NO. DE - AC07 - 79ID12050

for the Idaho Operations Office

Bechtel National, Inc.

San Francisco, California

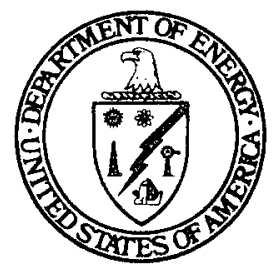

\section{U. S. DEPARTMENT OF ENERGY Geothermal Energy}




\section{DISCLAIMER}

This report was prepared as an account of work sponsored by an agency of the United States Government. Neither the United States Government nor any agency Thereof, nor any of their employees, makes any warranty, express or implied, or assumes any legal liability or responsibility for the accuracy, completeness, or usefulness of any information, apparatus, product, or process disclosed, or represents that its use would not infringe privately owned rights. Reference herein to any specific commercial product, process, or service by trade name, trademark, manufacturer, or otherwise does not necessarily constitute or imply its endorsement, recommendation, or favoring by the United States Government or any agency thereof. The views and opinions of authors expressed herein do not necessarily state or reflect those of the United States Government or any agency thereof. 


\section{DISCLAIMER}

Portions of this document may be illegible in electronic image products. Images are produced from the best available original document. 
ABSTRACT

The production of ethanol from potatoes, sugar beet, and wheat using geothermal resources at the Raft River area of Idaho is being evaluated. The south central section of Idaho produces approximately $18 \mathrm{million}$ bushels of wheat, $1.3 \mathrm{mill}$ ion tons of sugar beet and 24 million cwt potatoes annually. Based on these production figures, a 20 million gallon/yr ethanol facility has been selected as the largest scale plant that can be supported with the current agricultural resources. The plant will operate on all three feedstocks nominally processing potatoes for five months, sugar beet for four months and wheat for three months of the year.

The process facility will use conventional alcohol technology utilizing geothermal fluid at a maximum of $280^{\circ} \mathrm{F}$ as an energy source. The process flow diagrams for all three feedstocks are currently being prepared. There will be basically three feedstock preparation sections, although the liquefaction and saccharification steps for potatoes and wheat will involve common equipment. The fermentation, distillation and by-product handling sections will be common to all three feedstocks.

Three geothermal energy extraction systems were considered to accommodate the energy requirements of the ethanol facility (flashed steam, pressuized fluid and secondary heat transfer). Pressurized geothermal fluid with direct heat transfer has been selected as the usage mode to minimize scale deposition. Tentatively, the geothermal supply wells will be laid out in square grids with $1 / 4$ mile spacing. The number of wells required will be determined after the process heat load is calculated. 
TABLE OF CONTENTS

Figures • • • • • • • • • • • • • • • • • • • • iii Tables . . . . . . . . . . . . . . . . . . . . iv

Section

$\underline{\text { Page }}$

1 TNTRODUCTTON • • • • • • • • • • • • • • • • • 1-I

2

ETHANOL PRODUCTTON TECHNOLOGY. • • • • • • • • 2-I

2.1 Feedstock Requirement . . . . . . . . . 2-1

2.2 Feedstock Preparation . . . . . . . . 2-4

2.3 Saccharification and Fermentation . . . . 2-6

2.4 Anhydrous Ethanol Production . . . . . . 2-8

2.5 By-Product Processing . . . . . . . . 2-9

3 PROCESS FLOW DIAGRAM PREPARATION . • . • . . • $3-1$

3.1 Establishment Process Conditions and Scope. 3-1

3.2 Process Flow Diagrams . . . . . . . . 3-2

3.3 Sugar Beet Processing. . . . . . . . 3-2

3.4 Potato Processing Description . . . . . $3-19$

3.5 Wheat Processing. . . . . . . . . . 3-29

4 GEOTHERMAL RESOURCE • • • • • • • • • • . • 4-1

4.1 Resource Extraction and Requirement . . . . 4-1

4.2 Geothermal Fluid Properties . . . . . . 4-3 
TABLE OF CONTENTS

(continued)

Section

Page

5

CONCEPTUAL DESIGN OF GEOTHERMAL ENERGY

GATHERING, TRANSFER, AND DISPOSAL SYSTEM . . . 5-1

5.1 Well Field Design . . . . . . . . . 5-1

5.2 Brine Gathering System . . . . . . . 5-4

5.3 Brine Disposal. . . . . . . . . 5-4

6

ECONOMIC FACTORS • . . . . . . . . . . . . 6-1

6.1 Geothermal Well Costs... . . . . . 6-1

6.2 Crook's Property . . . . . . . . . . 6-1

6.3 Glover's Prospect . . . . . . . . . 6-2

6.4 Electric Rates . . . . . . . . . 6-2

6.5 Cooling Water . . . . . . . . . 6-2

REFERENCES 


\section{FIGURES}

Number

$\underline{\text { Page }}$

1-1 Well and Pipeline Location

Raft River Area. . . . . . . . . . 1-2

3-1. Block Flow Diagram Sugar Beet Processing

$20 \mathrm{MM} \mathrm{Gal/Yr}$ Ethanol Plant . . . . . 3-7

3-2 20 MM Gal/Yr Nominal Ethanol Facility

Sugar Beet Processing - Preliminary

Process Flow Diagram . . . . . . . 3-8

3-3 20 MM Gal/Yr Nominal Ethanol Facility

Sugar Beet Processing - Preliminary

Process Flow Diagram . . . . . . . 3-9

3-4 Block Flow Diagram Potato Processing 20 MM Gal/Yr Ethanol Plant ... . . . 3-24

3-5 $20 \mathrm{MM} \mathrm{Gal/Yr}$ Nominal Ethanol Facility

Preliminary Potato Processing

Process Flow Diagram . . . . . . . 3-25

3-6 20 MM Gal/Yr Ethanol Facility

Preliminary Product Recovery

potato Case... . . . . . . . 3-26

4-1 Relative Energy Cost vs

Brine Return Temperature . . . . . 4 4-2 


\section{TABLES}

Recent Potato Production in South Central Idaho . . . . . . . 2-3

Average Composition of Sugar Beet (Clean) . . 3-3

3-2 Principal Design Bases - Processing Sugar Beets... . . . . . . . 3-5

3-3 Principal Design Bases - Fermentation Sugar Beets... . . . . . . . . 3-14

Average Potato Composition (Clean). . . . 3-20

$3-5$

Principal Design Bases - Processing potatoes potato Fermentation . . . . . . . 3-22 


\section{Section 1}

\section{INTRODUCTION}

The existence of extensive geothermal resources in the United States represents an untapped potential energy source to supplement available fossil fuels. High temperature geothermal resources $\left(<350^{\circ} \mathrm{F}\right)$ will most 1 ikely be used to generate electricity. However, such high temperature resources are limited. Extensive studies by the U.S. Geological Survey and others have shown that low temperature resources are much more abundant. These lower temperature geothermal resources are suitable for direct use. A number of direct applications for space heating and agriculture uses are currently in existence. These applications by their nature are limited to energy consumption at or near the geothermal source. For this study the use of geothermal energy for the production of ethanol as a fuel is being evaluated. Ethanol produced with geothermal resources will be able to convert the non-mobile energy to a mobile form to supplement our automotive fuel requirements.

This technical and economic evaluation of ethanol production using geothermal resources is specifically directed to a site adjacent to the Department of Energy Raft River Test Facility. The locations of the properties owned by Messrs. G. Crook, et. al and Frank Glover referred to in this study are shown in Figure $1-1$. 


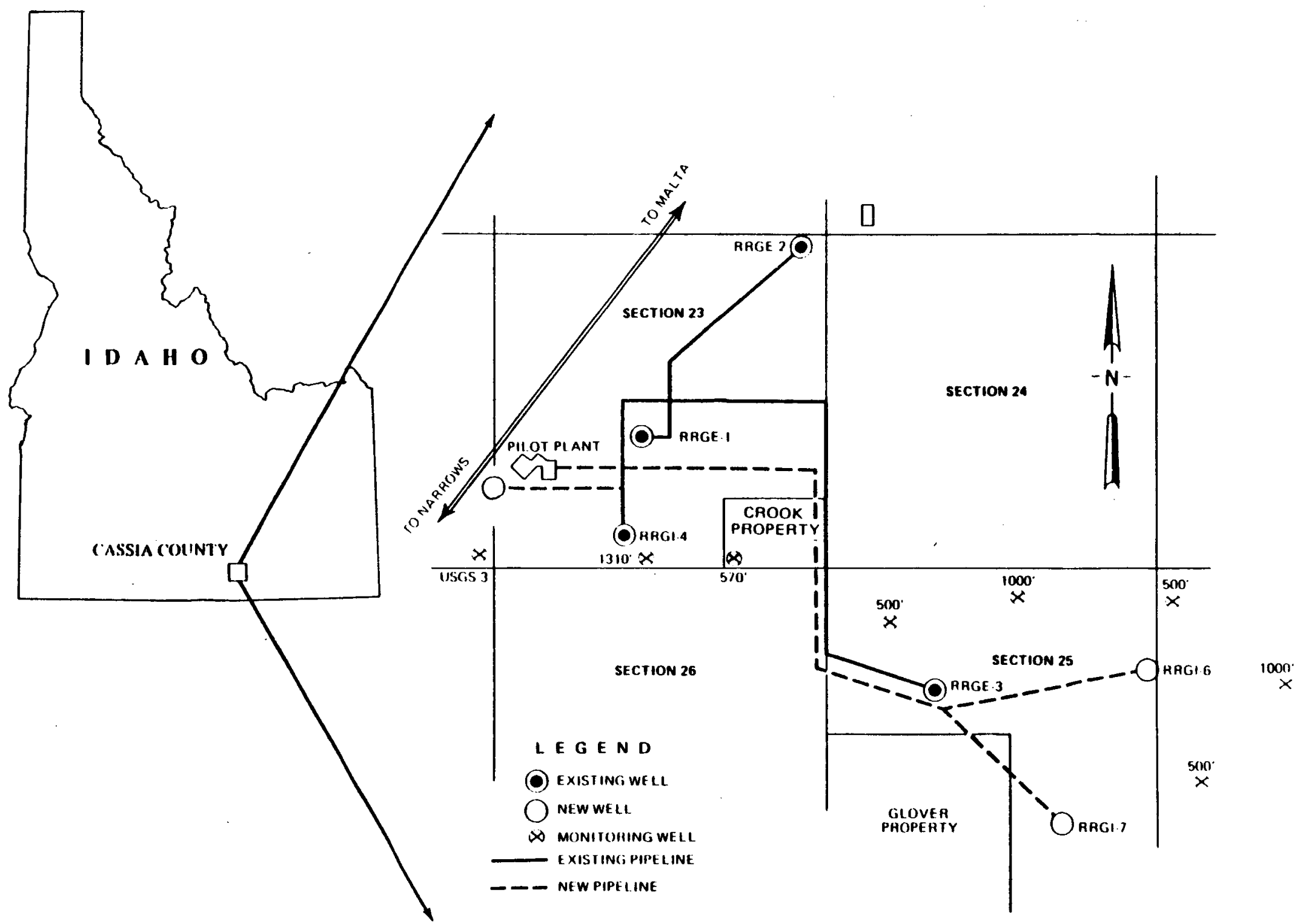

Figure 1-1 WELL \& PIPELINE LOCATION - RAFT RIVER AREA

REF: ISEMI-ANNUAL PAOGRESS REPORT FOR IDAHO GEOTHERMAL PROGRAM, 10/1/77 TO 3/31/78, E.G. \& G IDAHO, INC., JULY 1978, TREE-1278I 
This study is divided into nine major tasks to --

- Evaluate the availability of farm products in the Raft River region to produce ethanol.

- Provide the necessary conversion process.

- Establish the conditions and availability of the geothermal resource.

- Provide an economic analysis.

- Determine institutional requirements for commercial operation.

The nine tasks, including all of the subtasks, are shown in Table 1-1.

The study was begun on July 2, 1979. This report covers results accomplished from the inception of the project to the last week of September 1979. 
Table $1-1$

SCOPE OF WORK

Task 1 Define Current Ethanol Production Technology

1.1 Feedstock Requirement

1.2 Feedstock Preparation

1.3 Saccharification and Fermentation

1.4 Anhydrous Ethanol Production

1.5 By-product Processing

Task 2 Process Flow Diagram Preparation

2.1 Establish Process Conditions and Scope

2.2 Prepare Alternative PFD's for Selected Feedstocks

2.3 Establish Process Requirements

Task 3 Definition of Geothermal Resource Requirements

3.1 Process Conditions

3.2 Establishment of Geothermal Brine Flow Requirements

3.3 Study of Physical and Chemical Constraints

Task 4 Conceptual Design of Geothermal Energy Gathering Transfer and Disposal Systems

4.1 Well Field Design

4.2 Brine Gathering System

4.3 Energy Extraction System

4.4 Brine Disposal

4.5 Resource Property Variations

4.6 System Optimization 
Table 1-1

(continued)

Task 5 Conceptual Design of Alcohol Facility

5.1 Definition of Overall Facility

5.2 Preparation of Process Equipment Specifications

5.3 Establish Facility and Equipment Lists

Task 6 Economic Analysis of Geothermal-Alcohol Scheme

6.1 Capital Cost Estimate

6.2 Operating Cost Analysis

6.3 Economic Evaluation and Comparison with Other Energy Sources

Task 7 Implementation Plan for Demonstration Facility

7.1 Define Program Goals

7.2 Information Transfer

7.3 Technical Demonstration

Task 8 Site Institution Requirement for Demonstration Project

8.1 Feedstock Availability

8.2 Environmental Effects

8.3 Resources Leasehold Arrangement

8.4 Procedural Considerations

Task 9 Final Report 
Section 2

ETHANOL PRODUCTION TECHNOLOGY

\section{$2.1 \quad$ Feedstock Requirement}

Wheat, sugar beets and potatoes were selected as the candidate raw materials for ethanol fermentation. Over the past few years (1975-1978), production of each of these crops in the counties around the Raft River Geothermal project has been sufficient to support a "commercial-scale" ethanol production facility $(20 \mathrm{MM}$ gal/yr or larger). The following shows the average annual production:

$$
\begin{aligned}
& \text { - } \begin{array}{l}
\text { Wheat (winter) } \\
\text { - Wheat (spring) } \\
\text { - Sugar beets } \\
\text { - Potatoes }
\end{array} \quad 2,0000,000 \text { bushels } \\
& \text { - }
\end{aligned}
$$

Tables 2-1, 2-2, and 2-3 summarize the approximate production by counties. These quantities cannot be considered as the resources available solely for ethanol production. One cannot introduce a new demand equivalent to the existing demand for these agricultural products without seriously upsetting the local market conditions. In order to obtain raw materials at a reasonable price, the total demand must be kept close to the achievable production in the area. About 40 percent of the total cropland in these five counties is used for these three crops. Other cropland acreage 
Table 2-1 (Ref. 2)

Recent Wheat Production

in South Central Idaho

\begin{tabular}{|c|c|c|c|c|c|c|c|}
\hline \multirow[t]{2}{*}{ County } & \multicolumn{3}{|c|}{ Winter wheat } & \multicolumn{4}{|c|}{ Spring wheat } \\
\hline & $\begin{array}{l}\text { acreage } \\
\text { planted }\end{array}$ & $\begin{array}{l}\text { yield p } \\
\text { bu/ac. }\end{array}$ & $\begin{array}{l}\text { production } \\
\text { MM bu }\end{array}$ & $\begin{array}{l}\text { acreage } \\
\text { planted }\end{array}$ & $\begin{array}{l}\text { yield } \\
\text { bu/ac. }\end{array}$ & prc & $\begin{array}{l}\text { duction } \\
\text { MM bu }\end{array}$ \\
\hline $\begin{array}{l}\text { Cassin } \\
\text { Jerome } \\
\text { Minidoka } \\
\text { Twin Falls } \\
\text { Powers }\end{array}$ & $\begin{array}{r}60,000 \\
15,000 \\
10,000 \\
20,000 \\
125,000 \\
\end{array}$ & $\begin{array}{l}46 \\
76 \\
70 \\
66 \\
34\end{array}$ & $\begin{array}{r}2.76 \\
1.14 \\
.7 \\
1.32 \\
4.25 \\
\end{array}$ & $\begin{array}{l}35,000 \\
16,000 \\
22,000 \\
20,000 \\
40,000 \\
\end{array}$ & $\begin{array}{l}71 \\
69 \\
75 \\
76 \\
45\end{array}$ & & $\begin{array}{l}2.48 \\
1.10 \\
1.65 \\
1.52 \\
1.8 \\
\end{array}$ \\
\hline Totals & 230,000 & $44.2 \mathrm{avg}$ & 10.17 & 133,000 & 64.3 & avg & 8.55 \\
\hline
\end{tabular}

Table 2-2 (Ref. 2)

Recent Sugar Beet Production

in South Central Idaho

\begin{tabular}{lccr}
\hline County & $\begin{array}{c}\text { acreage } \\
\text { planted }\end{array}$ & $\begin{array}{c}\text { yield } \\
\text { tons/ac }\end{array}$ & $\begin{array}{r}\text { production } \\
\text { tons }\end{array}$ \\
Cassin & 17,000 & 18 & 306,000 \\
Jerome & 5,000 & 18 & 40,000 \\
Minidoka & 30,000 & 18 & 540,000 \\
Twin Falls & 14,000 & 20 & 280,000 \\
Power & 8,000 & 16.5 & 132,000 \\
\multicolumn{1}{c}{ Totals } & 74,000 & $18.2 \mathrm{avg}$ & $1,348,000$ \\
\hline
\end{tabular}


Table 2-3 (Ref. 2)

Recent Potato Production

in South Central Idaho

\begin{tabular}{lrcc}
\hline County & $\begin{array}{c}\text { acreage } \\
\text { planted }\end{array}$ & $\begin{array}{l}\text { yield } \\
\text { cwt/ac }\end{array}$ & $\begin{array}{c}\text { production } \\
\text { cwt }\end{array}$ \\
Cassia & 25,000 & 245 & $6,125,000$ \\
Jerome & 15,000 & 265 & $3,975,000$ \\
Minidoka & 35,000 & 235 & $8,225,000$ \\
Twin Falls & 19,000 & 300 & $2,700,000$ \\
Power & 16,000 & 235 & $3,760,000$ \\
\multicolumn{1}{c}{ Totals } & 110,000 & 225 avg & $24,785,000$ \\
\hline
\end{tabular}

could be used to increase production, however irrigation water is in limited supply. Rather than attempt to markedly increase the production of one of these potential feedstocks, the strategy should be to seek a fraction of each crop's annual production for feedstock and to work with the growers associations to ensure that there will be adequate supplies for all the buyers.

This multi-crop feedstock concept has been adopted for this study. A 20 million gallon per year ethanol production capacity was selected as being the largest scale than can be supported by the agricultural resources of the south central area. The facility would nominally process potatoes for five months, sugar beets for four months and wheat for three months of the year. 
In each year, crop productions and prices would dictate the actual processing $\mathrm{mix}$ and run duration so that the lowest cost (per gallon of production) feedstock would be purchased on the open market. Sugar beet acreage would be contracted far in advance through the growers association, so the process run on sugar beets is essentially fixed before planting time.

Only agricultural resources in the south central area of Idaho were considered. There is very little production of wheat, sugar beets and potatoes in the Utah counties just south of the Idaho-Utah state line. Truck shipment of these materials from other producing areas in Idaho and perhaps oregon would add too much to the cost of the materials to be an economic alternative.

\subsection{Feedstock Preparation}

Feedstock preparation technology for wheat, sugar beets and potatoes was discussed with conventional processors (millers, sugar factories, starch plants and dehydrators) with equipment vendors and with saccharification/fermentation experts.

For each of the three feedtocks there are basically two preparation approaches: 1) whole product processing and, 2) refined product preparation. The second, and more costly approach, produces clean substrate material which is theoretically amenable to continuous fermentation. 
Whole product processing is conducive only to batch fermentation. For wheat and potatoes whole product processing schemes were chosen. Both require liquefaction and saccharification steps prior to fermentation. For the beet case, a partially refined product preparation scheme was selected, since there is little experience with fermentation of the whole beet (juice and pulp).

The preparation steps for wheat will tentatively consist of cleaning, then dry grinding with no separation followed by slurrying with water to a starch-dry solids (DS) content suitable for fermentation to produce approximately $10 \%$ ethanol. The $\mathrm{pH}$ of the slurry is adjusted to 6.5 in preparation for gelatinization and enzymatic liquefaction.

Potatoes are washed with water, drained and disintegrated without peeling. The ground potatoes are centrifuged to a DS content of 21 percent. The $\mathrm{pH}$ is adjusted to 6.5 as in wheat preparation prior to gelatinization and liquefaction.

Sugar beets are processed using conventional beet-sugar technology. The beets are washed with water, drained, sliced into thin strips (cossettes) and then the juice phase is extracted from the insoluble portion of the beets (pulp) in a hot water diffusion process. The thin juice contains about 14 percent sucrose and is partially concentrated before fermentation to ethanol. These feedstock preparations involve simple, well-established, physical processes. 
The refined product approach involves conventional separation processes which produce high quality starch (wheat and potatoes) and low impurity, concentrated juice (beets). The major by-product materials are produced in the preparation steps rather than in the post-fermentation processing.

In order to minimize the cost of the three feedstock preparation sections in the facility, the simpler approach was selected for this study.

\subsection{Saccharification and Fermentation}

Both potato and wheat starches must be converted into fermentable sugars. Enzymatic schemes were selected for liquefaction and saccharification based on starch conversion literature and discussions with enzyme producers. The processing conditions selected are well-established and the amylase enzymes required are commercially available. Processing steps for wheat and potato starch are nearly identical so the same equipment can be used for both:

- Addition of the liquefying enzyme (alpha amylase) to the raw starch slurry.

- Cooking the slurry to liberate the starch molecules (gelatinization) and to allow enzymatic breakdown of the starch bonds (liquefaction).

- Cooling the slurry and pH adjustment to 4.5 .

- Conversion of starch to glucose (saccharification) by addition of the saccharifying enzyme (glucoamylase) and holding the solution for about 48 hours. 
The saccharification step can be carried out simultaneously with fermentation with the penalty of a higher glucoamylase dose. A clean substrate is desirable.

Both batch fermentation and continuous fermentation schemes were considered in the process of selecting preparation steps for each feed material. Continuous fermentation offers the advantages of high fermentation rates (low residence time) and low yeast makeup requirements. It requires a clean substrate. Continuous fermentation is also more susceptible to contamination than the conventional batch process. The batch fermentation approach was chosen along with the whole product processing approach because of its relative simplicity and its proven reliability.

Batch fermentation consists of charging a fermentation tank with the sugar (glucose or sucrose) solution, addition of brewers yeast and nutrients and holding the mash for about 48 hours to allow completion of the sugar conversion to ethanol. Cooling is required to remove the heat of reaction, maintaining the mash temperature at about $30^{\circ} \mathrm{C}$. By-products of the reactions include yeast, carbon dioxide, fusel oils (high-molecular weight alcohols) and aldehydes.

After the fermentation period, the tank is emptied, cleaned and sterilized and is ready to receive another charge of sugar solution. Multiple fermentation tanks are employed 
to avoid enormous tank sizes and to reduce the total cycle time - fill, ferment, empty and clean.

The sugar solutions from beet and potato processing have lower than desired sugar contents for optimum fermentation and the subsequent distillation. Prior to fermentation both will be concentrated to be equivalent to the sugar content of the wheat processing solution.

2.4 Anhydrous Ethanol Production

The possibility of producing a 190 proof ethanol for blending with gasoline was abandoned early in this study by mutual agreement with DOE's Technical Representative.

The following distillation methods for producing anhydrous 200 proof ethanol were subsequently examined:

- Conventional low pressure stripping, rectification and benzene-water-ethanol azeotropic distillation.

- Vacuum distillation to avoid the water-ethanol azeotropic condition.

- Extractive distillation with gasoline to directly produce a gasoline/alcohol mixture.

- Distillation followed by vapor phase dehydration using adsorption agents.

The last two schemes offer promise of significant energy savings but are relatively undeveloped processes. Vacuum distillation does not appear to yield real cost/energy savings because of the greater investment in distillation 
equipment. Katzen (Ref. l) offers a dual-pressure distilmodification of the conventional process. However, it requires a steam temperature (from coal-fired boilers) that is considerably higher than that available from the geo-

The more conventional scheme was therefore selected:

- A beer still producing a 73 mole percent ethanol overhead and a stillage bottoms product with fusel oils taken off as a side draw.

- A benzene-water-ethanol azeotropic distilltion with anhydrous ethanol as bottoms product. Water from the benzene stripper is essentially free of benzene and ethanol.

\section{$2.5 \quad$ By-Product Processing}

By-product type and quantities were considerations in the selection of the preparation schemes for each feedstock. Refined product preparation produces a number of different front-end by-products. With a multiple feedstock facility, the handling, storage and marketing of a number of different by-product materials may not be attractive, even if some high-value materials such as gluten are produced. Process complexity and low utilization of process equipment are real drawbacks.

The whole processing approach carries the non-fermentables (except for beet pulp) through the process to the beer still. The whole stillage from each feed material contains yeast, other insolubles and dissolved solids from which a single- 
type of by-product-animal-feed would be recovered. Its advantage is a single recovery scheme that accommodates each feedstock.

Production of a wet by-product for animal feeding onsite was an option considered briefly. While it would produce a considerable energy savings by reducing drying requirements, the option adds complexity by introducing another industry into the area. The feedlot option may not be practical in the geothermal resource site area.

The by-product processing scheme selected involves:

- Centrifugal separation of whole stillage into a sludge and a thin liquor containing the dissolved solids.

- Evaporation of the thin Iiquor to a syrup-like product.

- Blending the syrup with the sludge and drying it with geothermal fluid as the heat source.

- Grinding the dry solids for storage and sale as dry animal feed.

Three separate dry products could be produced or they could be blended for sale as a single product. 
Section 3

PROCESS FLOW DIAGRAM PREPARATION

3.1 Establishment Process Conditions and Scope

The process conditions for the three feedstock have been generally established. Final conditions for wheat processing are subject to confirmation by a test being conducted at Novo Laboratories. There will be basically three feedstock preparation sections, although the liquefaction and saccharification steps for wheat and potatoes will involve common equipment. The fermentation, distillation and byproduct handling sections will be common to all three feedstocks. A design rate of $2540 \mathrm{gpm}$ of ethanol will be produced from the fermentation step. Twenty million gallons per year of $199^{\circ}$ proof ethanol will be recovered.

Utility resources assumed to be available for the processes are:

Electric power

$4.16 \mathrm{kV}, 3 \phi, 60$ Hertz at the plant fence line

Cooling water $60^{\circ} \mathrm{F}$ source from wells

Process water $60^{\circ} \mathrm{F}$ source from wells

Potable water $60^{\circ} \mathrm{F}$ source from wells

Hot water (max.temp.) $280^{\circ} \mathrm{F}$ geothermal water 


\subsection{Process Flow Diagrams}

The process flow diagram for each feedstock are in various stages of preparation. The following sections provide the status of the sugar beet processing and potato processing process flow diagrams at the end of the report period.

\subsection{Sugar Beet Processing}

Sugar beets are processed four continuous months each year, November through February, following 3 months of wheat processing. Three hundred twenty-one thousand tons of beets are received by the plant for cleaning and processing. On-site storage capacity is 120,000 tons. About 21,000 tons of trash and silt are removed in cleaning the beets over the four-month period. The daily slice contains 442 tons of sugar of which 432 tons are extracted as a thin juice in the diffusion process. The thin juice ( $13.85 \%$ sugar) is concentrated to $19 \%$ sugar. These 442 tons yield a net of 213.1 tons of ethanol (ca $91.6 \%$ net yield) at the end of batch fermentation of the concentrate juice. The beer (10.38 wt ethanol) is distilled to a $87 \%$ wt ethanol overhead product, then dehydrated to a $99.2 \%$ wt ethanol product in a benzene-water-ethanol column. Beet pulp from the diffusion step is dewatered and dried for by-product sale. The whole stillage from the beer still is evaporated to a syrup and dried with the beet pulp. Fusel oils (higher molecular weight alcohols) are also recovered as a byproduct which may be blended with the ethanol product. 


\section{Design Basis}

Table 3-1 presents the assumed composition of the sugar beets processed in the plant.

Table 3-1

Average Composition of Sugar Beet (Clean)

Soluble dry matter

$18.87 \%$

Marc

$5.00 \%$

Water

76.138

$100.00 \%$

JUICE

Sucrose

$16.00 \%$

N-free organics (carbohydrates, acids, saponins)

$1.20 \%$

$\mathrm{N}$-organics (betaine, amides, amino acids, purines,

$1.17 \%$ pyramidines, ammonia and nitrates)

Inorganics $\left(\mathrm{K}, \mathrm{Ca}, \mathrm{Mg}, \mathrm{Na}, \mathrm{PO}_{4}, \mathrm{Cl}, \mathrm{SO}_{4}\right)$

.508

Water

$76.13 \%$

Marc

Insoluble pectic material, proteins, saponins

1.258

Cellulose, lignin, hemicelluloses

$1.25 \%$

Bound water

$2.50 \%$ 
The as-delivered beets are assumed to contain a total of seven percent (on a clean beet basis) foreign matter -rocks, trash and silt. In cleaning the beets all foreign matter is removed and 0.1 percent of the soluble dry matter half sucrose) is assumed to be lost in washing (or in storage).

Beets are processed 24-hrs per day, seven days per week at a design stream factor of 90 percent -2769.44 tons per stream day or 2492.5 tons per day on a calendar day basis. Tables $3-2$ and $3-3$ summarize the principal design bases for each process section.

Each section is described below. Figure $3-1$ is an overall block diagram of the beet processing and Figure $3-2$ is a process flow diagram of the steps up to distillation. Figure $3-3$ shows the product recovery section.

Beet Receiving and Storage -- Sugar beets are shipped to the ethanol facility by end-dump tractor-trailers. The net load averages 25 tons. Trucks are weighed in (gross) and out (tare) to record the as received tonnages. At the scale trucks are directed to one of two dump stations, one for direct processing and the other for transfer to storage. Five trucks per hour are routed to the direct processing station where a hydraulic dump platform elevates the trucks to discharge the beets into the wet hopper. 
Table 3-2

PRINCIPAL DESIGN BASES - PROCESSING

SUGAR BEETS

Elevation and Normal Atmospheric Pressure

$4800-f t ; 12.24$ psia

Beet Receiving \& Storage

Receiving periods

Carrier

Loads per day

Direct process

Reclaim from storage

Maximum reclaim rate

Beet Washing

Flume water

Wash water

Direct recycle

Pond recycle

Lost to sludge

Beet Slicing

Slice rate

Compressed air to slicers (cleaning)

Knife block cycle time

\section{Diffusion}

Average diffusion temp. Draft

Length of cossettes

Diffuser constant

Diffusion time

Sugar in pulp

Sugar in sliced beets

Diffuser capacity daylight hours, 7-days per week

25-ton net tractor-trailers (end dump)

214 for 60 days max rate

1235 tpd

1728 tpd

$150 \mathrm{tph}$
924 tpd per machine

$30 \mathrm{Ib} /$ ton of beets sliced

4 hours $70^{\circ} \mathrm{C}+273^{\circ}=343^{\circ} \mathrm{K}$

$120 \mathrm{lb}$ juice/100 $1 \mathrm{~b}$ cossettes

$13 \mathrm{~m} / 100 \mathrm{~g} \cdot$ cossettes

$6.6 \times 10^{-5}$

$64 \mathrm{~min}$.

$.3529 \%$ wt (1.237\% wt on pulp)

$15.95 \% \mathrm{wt}$

3200 tpd 


\section{Table 3-2 (continued)}

\section{PRINCIPAL DESIGN BASES - PROCESSING}

SUGAR BEETS

\section{Pulp Dewatering}

Raw pulp moisture

Screened pulp moisture

pressed pulp moisture

Sugar loss in pulp

Press water return

Utility and Energy Requirements

Electric power

Process water Cooling water

Hot geothermal water

Geothermal steam

Thin Juice Concentration

Sucrose exit concentration

Number of effects

Heat recovery

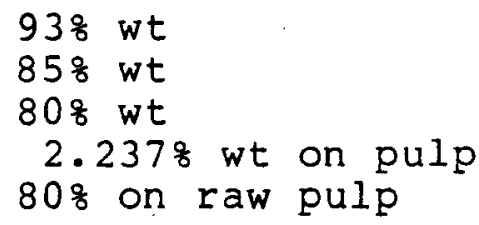

$93 \%$ wt

$858 \mathrm{wt}$

$808 \mathrm{wt}$

$2.237 \%$ wt on pulp

$80 \%$ on raw pulp
19.8 percent weight 2
preheating, water heating and diffuser heating




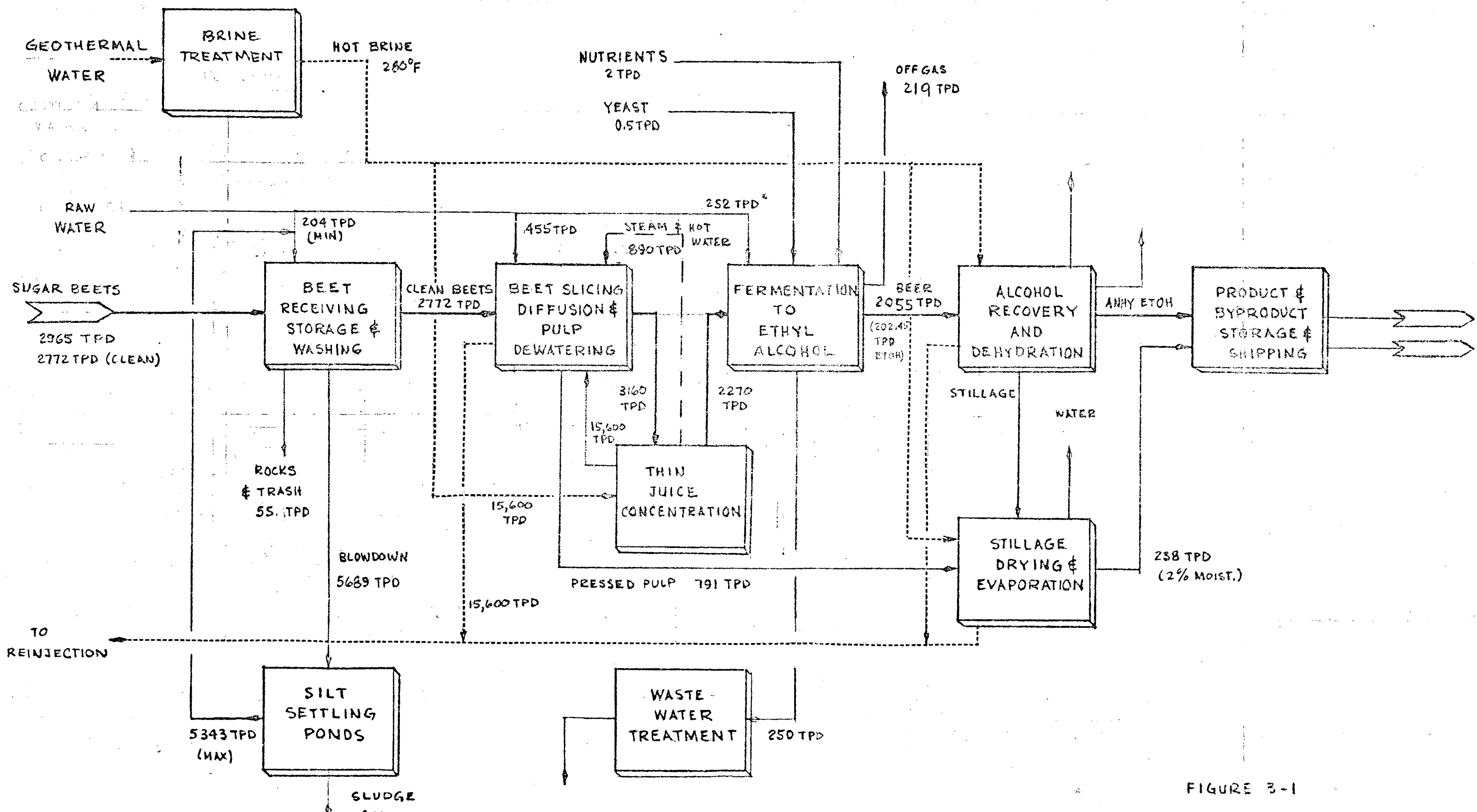

BLOCK FLOW DIAGRAM

SUGAR BEET PROCESSING

20 MM GAL/YOL ETHANOL PLANT 


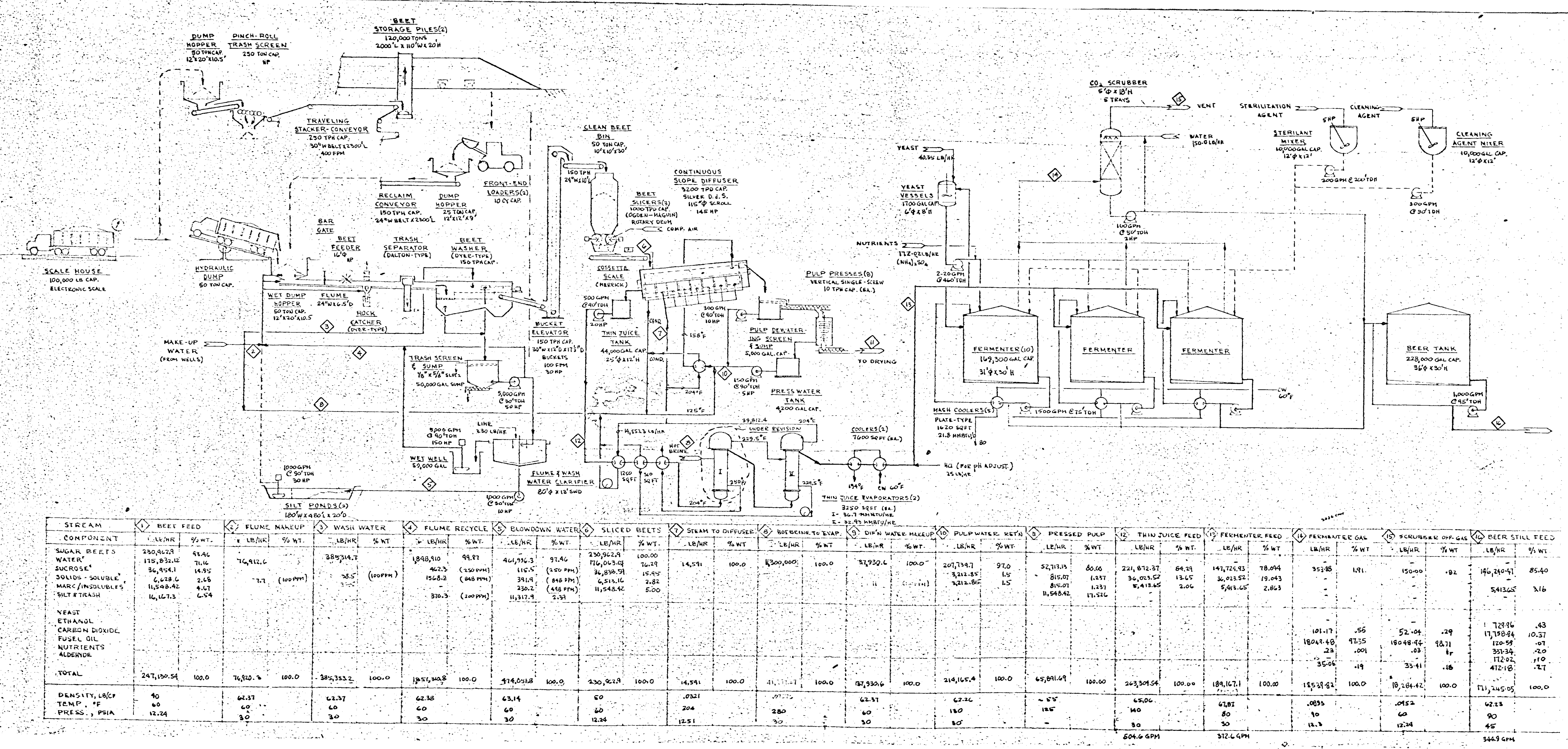

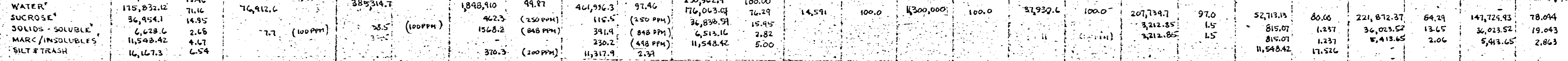




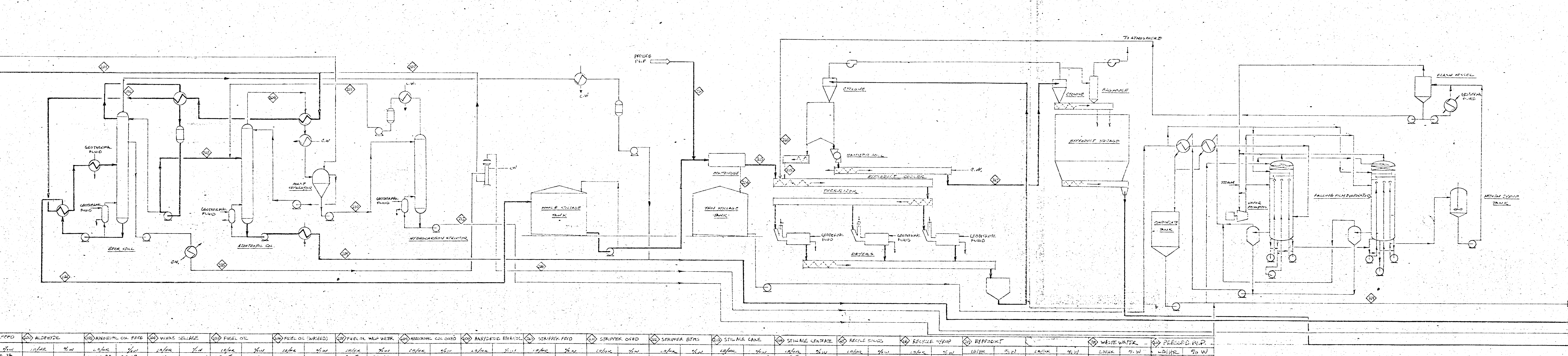


At the other dump station beets are dumped into a dry hopper and fed onto a pinch-roller trash screen which removes weeds and leaves. A traveling-stacker conveyor transfers the beets to one of two parallel storage piles. A transverse slewing boom is used to stack the beets up to a height of twenty feet and to a width of 115 feet. At full capacity, each pile will contain 60,000 tons. Transverse air ducts, spaced at $25 \mathrm{ft}$. intervals, distribute ventilation air supplied by low pressure fans.

Beets are reclaimed at up to 150 tons per hour by frontend loaders working the toe of a pile. They load a moveable hopper positioned above the reclaim belt conveyor. The reclaim conveyor discharges into the wet dump hopper from which beets enter the flume system.

Beet Washing -- The beets are cleaned to remove rocks, trash and soil prior to slicing. Beets are sluiced into the flume system with a mixture of fresh and recycled flume water. A feeder which in the flume regulates the flow of beets into the downstream portion of the flume. A Dyer-type rock catcher removes rocks from the lighter beets using an upward flow of water to lift the beets and allow the rocks to settle downward in the rock chute. A chain conveyor removes the collected rocks. Weeds, leaves and beet tails are removed in a Dalton-type trash separator. The trash is discharged from a rotating drum 
onto a belt conveyor for trash disposal. The beets return to the flume and enter the washer which has a dewatering section at the inlet. Fresh water is added as the beets pass onto a curved screen and are washed by sprays and by agitation. Clean beets are discharged by a dewatering screw onto a belt conveyor. Flume water and wash water pass over a trash screen and into a sump. The water can be recycled directly or discharged to a gravity clarifier for cleanup. Silt settles out in the clarifier and is pumped to one of two silt ponds. The clarifier overflow (about 80 percent) is recycled to the head end of the flume. The silt ponds allow further clarification to occur so additional water can be recycled. Sludge accumulates in the ponds and is dredged at the end of the beet processing season.

Beet Slicing -- Washed beets are conveyed to a bucket elevator which lifts them to a horizontal transfer conveyor above the 50 ton capacity clean beet bin. The bin is mounted above three 1000 ton per day capacity rotary slicers. Rotating knife blocks cut the beets into thin slices (cossettes). The knife blocks are changed out about every four hours for sharpening. Compressed air is used to clean the blocks during operation. The cossettes are fed onto a weigh belt conveyor (weightometer) which automatically weighs and totals the daily slice. 
Diffusion -- Hot water extraction of the juice from the cossettes is carried out in a continuous slope diffuser. The 3200 ton per day capacity Silver D.d.S. diffuser is steam jacketed to maintain the juice and pulp at the desired temperature $\left(160^{\circ} \mathrm{F}\right.$ average). Cossettes enter the lower end and are conveyed upward by the scrolls. Hot water and pulp return water enter the top end and pass downward countercurrently contacting the cossettes. By diffusion the juice phase passes from cellular material into the liquid. Exhausted cossettes (pulp) are discharged from the top end of the diffuser and drop onto a dewatering screen. The thin juice is dischargd (on level control) from the low end of the diffuser into a tank. The thin juice amounts to about 120 percent based, in the weight of the entering cossettes. The sugar content is 13.65 percent and represents a 97.8 percent sugar recovery.

Pulp Dewatering -- The raw pulp is screened to remove free water and then conveyed to eight vertical screw presses for dewatering to about 80 percent moisture content. Nearly 33 tons per hour of pressed pulp are generated. This material is conveyed to by-product drying. Screening water and press water are pumped through a heat exchanger and returned hot $\left(158^{\circ} \mathrm{F}\right)$ to the diffusion water inlet. Heated makeup water is also added to the return water stream ahead of the heat exchanger. Steam preheating the water helps to control bacterial growth in the diffuser. 
Thin Juice Concentration -- Multiple-effect evaporation is used to raise the sugar concentration in the juice for optimum fermentation and alcohol recovery. A modified two-effect evaporator system raises the sugar concentration to 19.8 percent weight. Hot geothermal brine $\left(280^{\circ} \mathrm{F}\right)$ in the first effect vaporizes water which is used as steam to the second effect. The evaporator condensates along with vapor from the second effect preheat the thin juice feed. The remaining vapor from the second effect provides all of the diffuser's steam needs. The coincentrated juice is then cooled to $80^{\circ} \mathrm{F}$ prior to fermentation.

Fermentation -- Fermentation of the sucrose solution is carried out batch-wise in ten 170,000 gal fermenters to yield a net 2540 gallons per hour of ethanol. Table 3-3 summarizes the fermentation parameters. The total cycle time per fermenter is 60 hours and eight batches are always in some stage of fermentation at any one time. One fermenter is being filled and one is being emptied and cleaned at any one time.

At the start of a cycle, concentrated juice, yeast and nutrients are pumped into the fermentation tank. $\mathrm{HCl}$ is added in-line to drop the $\mathrm{pH}$ to 4.5 from 6.5 . As the fermentation proceeds, heat released by the reaction increases the mash temperature. Carbon dioxide formed in the reaction also is released into the vapor space. 
Table 3-3

PRINCIPAL DESIGN BASES - FERMENTATION

SUGAR BEETS

Chemical Reactions and Conversions (Basis 100 lb glucose)

Sucrose hydrolysis (100\%)

$$
\begin{array}{ll}
\mathrm{C}_{12} \mathrm{H}_{22} \mathrm{O}_{11}+\mathrm{H}_{2} \mathrm{O} \longrightarrow & 2 \mathrm{C}_{6}{ }^{\mathrm{H}} 12{ }^{\mathrm{O}_{6}} \\
95.01 \mathrm{~b}+5.01 \mathrm{~b} & 100.01 \mathrm{~b}
\end{array}
$$

\section{Glucose conversion}

to ethanol $(91.888)$

$$
\begin{array}{ll}
\mathrm{C}_{6} \mathrm{H}_{12} \mathrm{O}_{6} \longrightarrow \text { yeast } \longrightarrow & 2 \mathrm{C}_{2} \mathrm{H}_{5} \mathrm{OH}+2^{2} \\
91.82 \mathrm{lb} & 46.971 \mathrm{~b} \quad 44.851 \mathrm{~b}
\end{array}
$$

to yeast $(3.636 \%)$

$$
\begin{aligned}
& \mathrm{C}_{2} \mathrm{H}_{12} \mathrm{O}_{6} \underset{\text { innoculum }}{\longrightarrow} \\
& 3.6363 \mathrm{Ib} \\
& 1.8181 \mathrm{lb} .9091 \mathrm{lb} .9091 \mathrm{lb}
\end{aligned}
$$

to other organics $(4.545 \%)$

$2.5 \mathrm{C}_{6} \mathrm{H}_{12} \mathrm{O}_{6} \longrightarrow 3 \mathrm{CH}_{3} \mathrm{CHO}+4 \mathrm{CO}_{2}+\mathrm{CH}_{3}\left(\mathrm{CH}_{2}\right)_{3} \mathrm{CH}_{2} \mathrm{OH}+3 \mathrm{H}_{2} \mathrm{O}$
$4.54541 \mathrm{~b}$
$1.33331 \mathrm{~b} \quad 1.7771 \mathrm{~b}$
$.8897 \mathrm{lb} \quad .5451 \mathrm{~b}$

Fermentation --

Yeast Makeup

Nutrient Requirements

Fermentation Time

Fermentation Temperature
$0.2385 \mathrm{lb} / 100 \mathrm{lb}$ ethanol produced $0.954 \mathrm{Ib} / 100 \mathrm{lb}$ ethanol produced 48 hours $85^{\circ} \mathrm{F}-90^{\circ} \mathrm{F}$ 
Table 3-3 (continued)

PRINCIPAL DESIGN BASES - FERMENTATION

$22 \mathrm{kcal} / \mathrm{g}-$ mole $(430 \mathrm{Btu} / \mathrm{lb}$ ethanol)

Fermenter Fill Time 6 hours

Fermenter Empty \& Clean Time 6 hours

Total Batch Cycle Time 60 hours

Maximum/Design Capacity $\quad 120 \%$

Off-gas Scrubbing --

Vapor superficial velocity 3 feet per second

$\mathrm{L} / \mathrm{G} \quad 20 \mathrm{gal} / 1000 \mathrm{ACFM}$

Pressure drop 2 in. W.G.

Gas inlet temperature $\quad 90^{\circ} \mathrm{F}$ (avg)

Gas exit temperature $\quad 60^{\circ} \mathrm{F}$ (avg)

Liquid circulation temp. $\quad 60^{\circ} \mathrm{F}$ (avg)

Makeup water replacement of water in off-gas

\section{Beer Well}

$\begin{array}{ll}\text { Surge capacity } & 8 \mathrm{hrs} \text { \& } 80 \% \text { full } \\ \text { Recirculation rate } & 1500 \mathrm{gpm}\end{array}$


The mash is circulated through plate-type exchangers when the bulk temperature reaches about $90^{\circ} \mathrm{F}$. Cooling water $\left(60^{\circ}\right.$ F) removes the bulk of the heat of reaction and 1 imits the mash temperature rise. Cooling is required only part of the fermentation time so one exchanger can be used to serve two fermenters. Alternately, the mash is circulated continuously, most of the time bypassing the exchanger. Evolved vapors, mainly $\mathrm{CO}_{2}$, are water-scrubbed in a tray column to recover ethanol. Blowdown from the scrubber is pumped to the beer well. Scrubber off-gas is vented to the atmosphere.

At the end of the 48 hour fermentation period, the fermented mash containing $9.8 \%$ ethanol is pumped to the beer well. The empty fermenter is chemically cleaned by internal spraying machines, sterilized with an iodine solution and rinsed with sterile water. The spent solutions are routed to wastewater treatment, and this tank is again ready for service.

The fermented mash (beer) charged to the beer well contains water, yeast, dissolved solids (organic and inorganic), fusel oil and aldehydes in addition to the ethanol. The net yield of ethanol based on sucrose is 91.6 percent. An eighthour surge capacity is provided and the tank contents are circulated continuously to provide a uniform feed to the distillation section. 
Ethanol Distillation -- Fermented beer from the beer well is preheated with the condensing vapors from the azeotropic column and the beer still through feed/tops exchangers to recover the condensing load of the vapor from both columns. The beer is further heated through a feed/bottoms exchanger taking additional heat from the bottom of the beer still. A trim heater using geothermal fluid will provide the final heat necessary to provide a bubble-point feed into the beer still.

The beer still is operated at a pressure of 10 psig at the bottom of the column, which corresponds to the maximum temperature available from the geothermal fluid for reboil duty in the thermosiphon reboiler. Fusel oil is concentrated in the upper part of the column and is removed and waterwashed in a separate fusel oil washer. The alcohol and water recovered from the fusel oil washer is returned to the beer still feed. Trace quantities of aldehyde produced in the fermenter is removed as an overhead stream. After condensation, the aldehyde is reblended with the ethanol product. Ethanol-water close to the azeotropic composition is condensed against the in-coming beer feed prior to its entry as a bubble-point feed to the azeotropic distillation column.

Benzene is used to form a ternary azeotrope with the ethanol/ water mixture in the azeotropic column. The water is removed overhead with the benzene. The condensed liquid is collected 
in a phase separator. The benzene in the upper phase is recycled back to the top of the column. The aqueous phase containing trace quantity of hydrocarbon is fed to a hydrocarbon stripper. The bottom stream of the azeotropic column is $99.2 \%$ ethanol. This stream is cooled and pumped to storage.

In the hydrocarbon stripper essentially all of the hydrocarbon remaining in the feed is removed overhead and fed back to the feed stream to the azeotropic column. The bottom stream is sent to wastewater treatment.

By-product Recovery -- The bottom stream from the beer still containing the yeast and dissolved solids is pumped to the whole stillage tank for further processing.

The whole stillage at this point combines with the beet pulp and is centrifuged to produce a thin stillage and a $35 \%$ solids stream for drying to produce an animal feed by-product.

The thin stillage is concentrated to 548 medium syrup through a mechanical vapor recompression falling film evaporator system. The condensate collected from this mechanical vapor recompression system is fed to the wastewater treatment system. 
The medium syrup combines with the centrifuged solids along with some recycled dried solids and fed to a turbulizer to mix these streams to yield a $45 \%$ solid stream as a feed to the geothermal fluid dryers. The final product from the dryers is $90 \%$ solid and $10 \%$ moisture. The dried product, part of which is recycled, is fed through a hammer mill for size reduction followed by cooling prior to its conveyance to the by-product storage awaiting shipment.

The material balance for this section of the plant is not complete at this time.

\subsection{Potato Processing Description}

Potatoes are processed for five continuous months each year, March through July, following the four months of sugar beet processing. 360,000 tons of potatoes are received by the plant for cleaning and processing during this period. Onsite storage capacity is 36,500 tons. The design mash rate is 2,630 tons of potatoes per day. The daily mash contains 389 tons of starch which is converted to 432 tons of sugar. At the end of batch fermentation, this sugar is converted to 203 tons per day of ethanol. The beer (11.25\% wt. ethanol) is distilled to a $87 \%$ wt. overhead product, then dehydrated to a 99.28 wt. ethanol product in a benzene-water-ethanol column. 
The whole stillage from the beer still is centrifuged. The cake is dried to $90 \%$ solids. Approximately 206 tons of this dried animal feed are produced per stream days. Fusel oils (higher molecular weight alcohols) are also recovered as a by-product.

\section{Design Bases}

Table 3.4 presents the assumed composition of the potatoes processed in the plant.

\begin{tabular}{lr}
\multicolumn{2}{c}{ Table $3-4$} \\
AVERAGE POTATO COMPOSTTJON & (CLEAN) \\
\hline Water & $77.5 \%$ \\
Starch & $15.0 \%$ \\
Proteins and fats & $2.1 \%$ \\
Fiber & $5.4 \%$ \\
&
\end{tabular}

All foreign matter is removed and 0.1 percent of the soluble dry matter is assumed to be lost in dewatering.

Potatoes are processed 24-hrs per day, seven days per week at a design stream factor of 90 percent (2630 tons per stream day). Tables 3.5 and 3.6 summarize the principal design bases for each process section. 
Table 3-5

PRINCIPAL DESIGN BASES - PROCESSING

POTATOES

Potato Receiving and storage

Receiving periods

daylight hours, 7-days per week

Carrier

20-ton net tractor-trailers (end dump)

$\begin{array}{ll}\text { Loads per day } & 130\end{array}$

Direct process $\quad 2607$ tpd

Potato Washing

Flume water

$1920 \mathrm{gal} / \mathrm{ton}$ of potatoes

flumed (design)

Wash water

$100 \mathrm{gal} / \mathrm{ton}$ of potatoes (design)

Direct recycle

98 percent (design)

Pond recycle

Lost to sludge

Potato Mashing

Mashing rate

870 tpd per machine

Mash Dewatering

Raw mash moisture

$78 \%$ wt

Dewatered mash moisture

$69 \%$ wt

Concentrate moisture

988 wt 
Table 3-6

PRINCIPAL DESIGN BASES - POTATO FERMENTATION

Chemical Reactions and Conversions (Basis 100 1b. glucose)

Starch hydrolysis $(100 \%)$

$$
\begin{aligned}
& \left(\mathrm{C}_{6}{ }^{\mathrm{H}} 10 \mathrm{O}_{5}\right)_{\mathrm{n}}+\mathrm{n} \mathrm{H}_{2} \mathrm{O} \longrightarrow \mathrm{n} \mathrm{C}_{6} \mathrm{H}_{12} \mathrm{O}_{6} \\
& \begin{array}{lll}
162 & 18 & 180
\end{array}
\end{aligned}
$$

Glucose conversion

to ethanol ( $91.818 \%)$

$\mathrm{C}_{6} \mathrm{H}_{12} \mathrm{O}_{6}$ yeast $2 \mathrm{C}_{2} \mathrm{H}_{5} \mathrm{OH}+2 \mathrm{CO}_{2}$.

$91.8121 \mathrm{~b} \quad 46.971 \mathrm{~b} \quad 44.851 \mathrm{~b}$

to yeast $(3.6368)$

$\mathrm{C}_{6} \mathrm{H}_{12} \mathrm{O}_{6} \stackrel{\text { innoculation }}{\longrightarrow}$ yeast $+1.452 \mathrm{CO}_{2}+1.452 \mathrm{H}_{2} \mathrm{O}$

$3.636 \mathrm{lb} \quad 1.8181 \mathrm{lb} .9091 \mathrm{lb} \quad .90911 \mathrm{~b}$.

to other organics $(4.545 \%)$

$2.5 \mathrm{C}_{6} \mathrm{H}_{12} \mathrm{O}_{6} \stackrel{\text { yeast }}{\longrightarrow} 3 \mathrm{CH}_{3} \mathrm{CHO}+4 \mathrm{CO}_{2}+\mathrm{CH}_{3}\left(\mathrm{CH}_{2}\right)_{3} \mathrm{CH}_{2} \mathrm{OH}+3 \mathrm{H}_{2} \mathrm{O}$

$\begin{array}{lllllllll}4.545 \mathrm{lb} & 1.3333 \mathrm{lb} & 1.777 \mathrm{lb} & .8897 \mathrm{lb} & 0.545 \mathrm{lb}\end{array}$ 
Each Process section is described below. Figure $3-4$ is an overall block diagram of the potato processing and Figure 3-5 is a process flow diagram of the steps up to distillation. Figure 3.6 shows the products recovery.

Potato Receiving and Storage -- Potatoes are shipped to the ethanol facility by end dump tractor-trailers. The net load averages 20 tons. Trucks are weighed in (gross) and out (tare) to record the as received tonnages. At the scale, trucks ae diverted to the dump station where potatoes are dumped into the potato cellar which provides storage space for 14 days' potato requirement $(36,500$ tons). Potatoes are reclaimed by front-end loaders working at the toe of a pile. The loaders transfer the potatoes to the reclaim belt conveyor which discharges into the slab storage area which provides potato storage for 8 hours of plant operation.

Potato Washing -- The potatoes are conveyed via a flume to one of three potato washers. Flume water is recycled. Wash water is supplied to each washer at 75 gallons per minute. The wash water flow from the washer to a twocompartment settling pond. Suspended solids settle out in the first compartment and clarified water flows into the second compartment from which it is recycled as flume water makeup. Sludge accumulates in the settling pond and is dredged at the end of the potato processing season. 


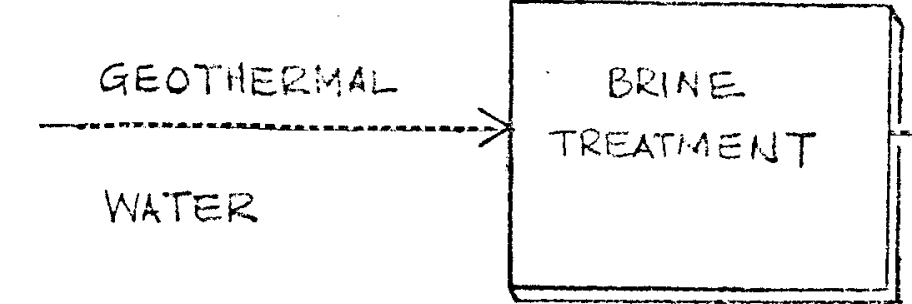

RAW

WATER

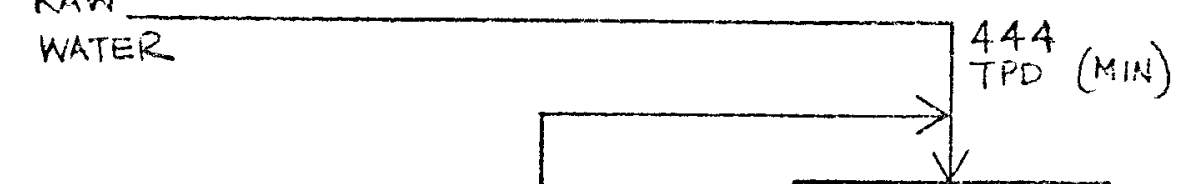

POTATO

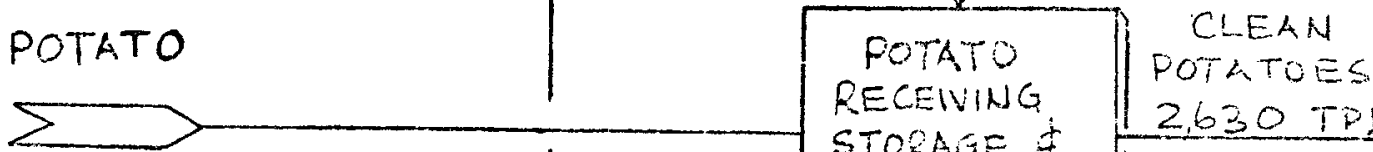

2,607 TPD STORAGE 12630 TPD

WASHING

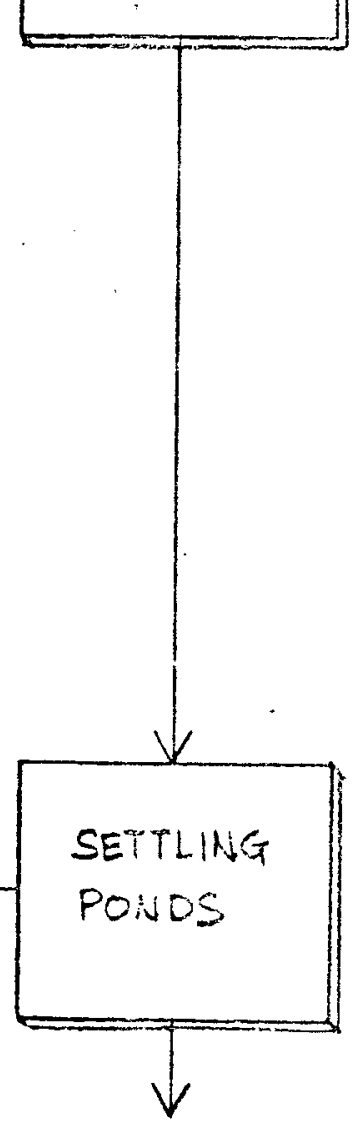

REINJECTION

$$
\begin{gathered}
\text { NaOH SOLUTHOH } \\
18 \text { TPD }
\end{gathered}
$$

CAMYLASE 0.6 TPD

GLUCOAMYLASE O.9TPO

HCI SOLUTION 6.5TPD
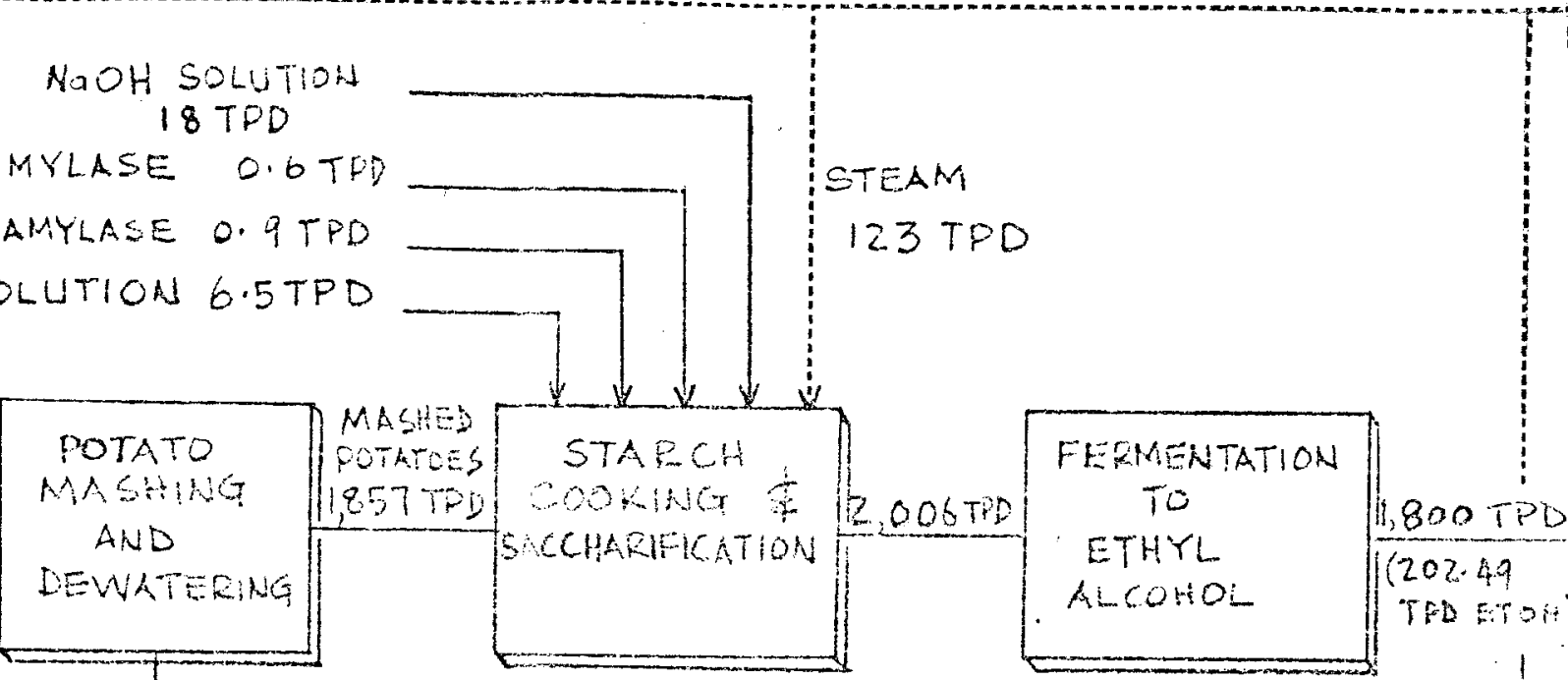

772 TPD

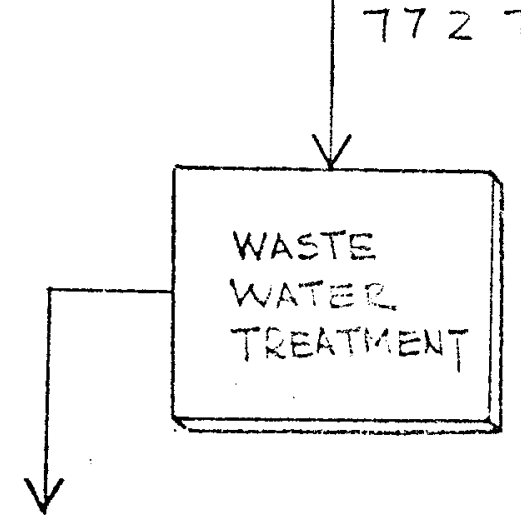

FIGURE $3-4$ BLOCK FLOW

DIAGRAM

POTATO PRDCESSING

$20 \mathrm{MM}$ GLGYR ETHADL FUMT 


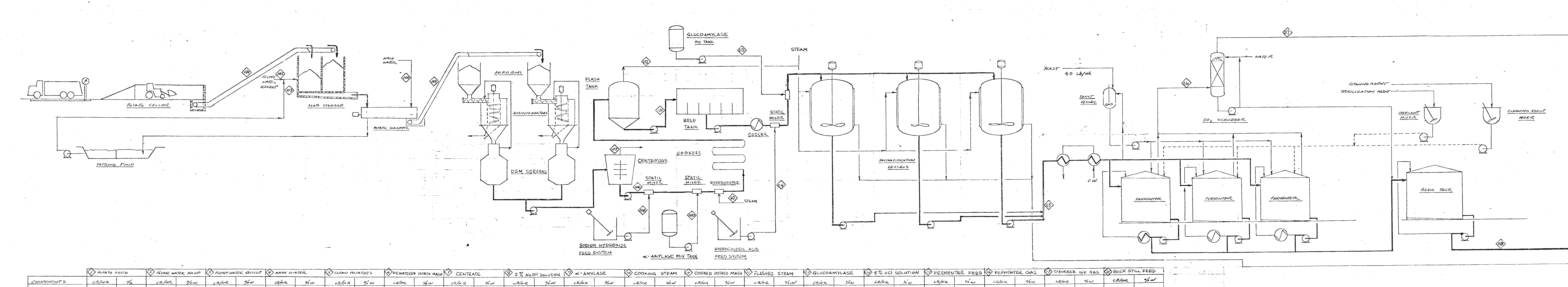

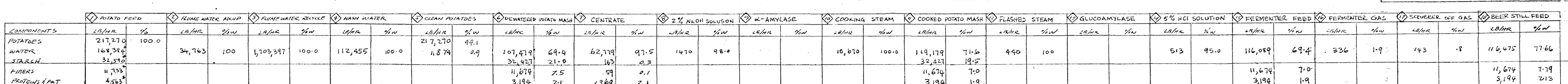


$\Rightarrow$
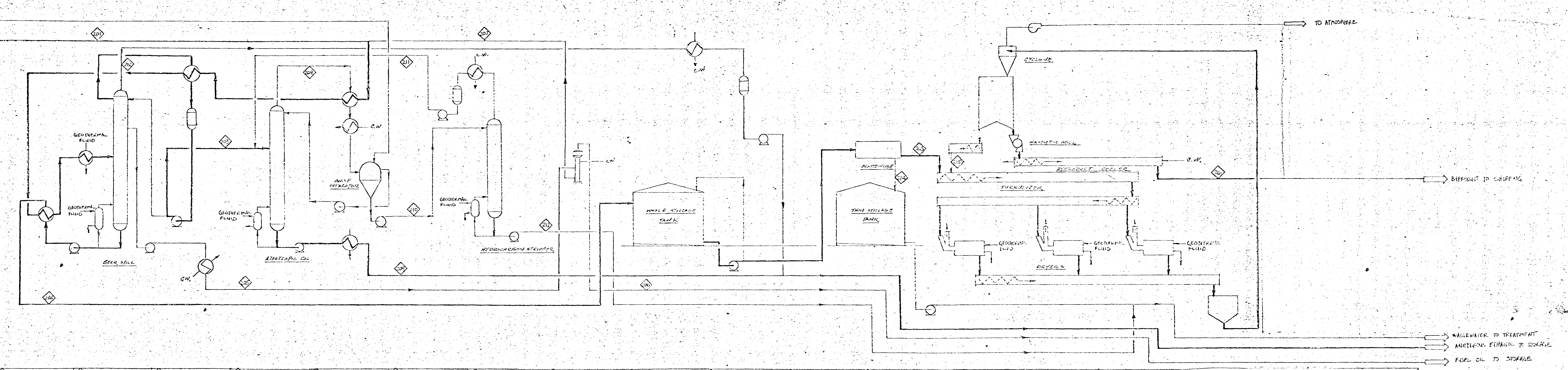

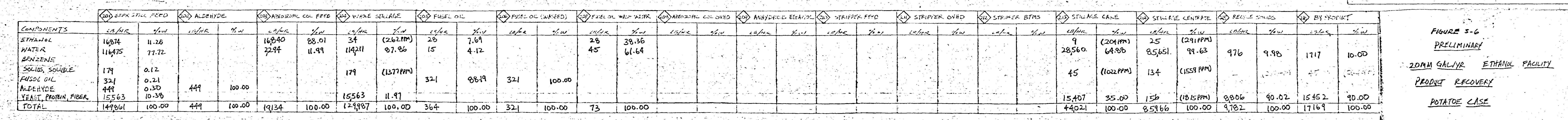


Potato Mashing and Dewatering -- Washed potatoes are conveyed to one of three feed bins and then to three disintegrators where the potatoes are crushed, and residual foreign matter (tramp iron, etc.) is separated from the mash and discharged to waste. The mash flows from the disintegrators to screens where course potato pieces are removed and recycled to the disintegrators. The screened mash flows to a centrifuge where its moisture content is reduced to approximately 69 percent. The centrate containing 0.3 percent starch, is discharged to the wastewater treatment facility.

Starch Liquefaction -- A two percent solution of sodium hydroxide is added in-line to raise the $\mathrm{pH}$ of the dewatered mash from 5.6 to 6.5. Alpha amylase is next added to the mash to break down the starch bonds and 10,670 pounds per hour of 10 psig direct steam are added to raise the temperature of the mash to $221^{\circ} \mathrm{F}$ for gelatinization and cooking of the starch. The starch is cooked for five minutes in a tubular cooker at $221^{\circ} \mathrm{F}$ and is then flash cooled to $203^{\circ} \mathrm{F}$. The cooked mash next enters a baffled hold tank which provides 90 minutes detention time. Agitators are provided for adequate mixing of the hold tank contents to prevent settling of suspended matter. The hold tank effluent is cooled to $140^{\circ} \mathrm{F}$ and treated with a five percent hydrochloric acid solution to lower the pH from 6.5 to 4.5 . 
Saccharification -- Glucoamylase is added to the liquified starch to break down the starch dextrins to produce a high yield of fermentable glucose. This takes place in ten 170,000 gallon saccharification vessels each with 60 hours retention time. A steam jacket around each saccharification vessel maintains the contents at $140^{\circ} \mathrm{F}$. Each vessel is also equipped with an agitator to ensure adequate mixing of the reactants.

Fermentation -- Fermentation of the glucose solution is carried out batch-wise in ten 170,000 gallon fermenters to yield a net 2540 gallons per hour of ethanol. Table 3-3 in the beet processing section summarizes the fermentation parameters. The fermentation conditions are identical to that described in the beet section.

Alcohol Distillation -- The distillation scheme for the potato case is identical to that described for the beet case except for a higher solids concentration bottom stream from the beer still in the potato case. The fibers from the potato processing were not separated prior to distillation, therefore all of the fibers come in with the beer feed to the still. 
By-product Recovery -- The whole stillage for the potato case has a much lower dissolved solids content than in the beet case. Therefore, the thin stillage produced from the centrifuge may go directly to wastewater treatment without being processed through the mechanical vapor recompression system. The energy consumption, therefore, is expected to be lower than that necessary for the sugar beet case.

The centrifuged solids from the whole stillage will be recovered in a similar manner to that described under the sugar beet case.

3.5 Wheat Processing

Work on the wheat processing option has been started. Equipment manufacturers have been contacted and a wheat processing plant (flour mill) was visited. Wheat milling tests are being conducted to determine whether removal of the gluten portion of the wheat in the milling section of the plant will have a favorable effect on process economics. The process flow diagram will be produced after the test results become available. 
Section 4

GEOTHERMAL RESOURCE

The overall process heat requirements will dictate the geothermal brine requirements. These have not been completed, but a preliminary estimate of the requirements is between 100 and 200 million BTU/hr. The following discussion covers how the geothermal brine will be used in the system and the brine flow requirements.

4.1 Resource Extraction and Requirement

Three different energy extraction systems were considered: (1) flashed steam; (2) pressurized geothermal fluid with a direct transfer of heat, and (3) use of a secondary heat transfer fluid. The pressurized fluid system has been selected since it minimizes the potential scaling problems in the brine transfer system. Thus, there will be no direct injection of the brine into the process streams. In the event steam injection is required, as in potato cooking, a secondary loop incorporating a steam generation system will be utilized.

Since the overall heat balance is not completed, only a preliminary estimate can be made for the geothermal fluid flow requirements. Figure 4-1 shows the relationship between geothermal fluid return flow temperature and this number of wells required and the relative energy cost to supply the process heat load. 


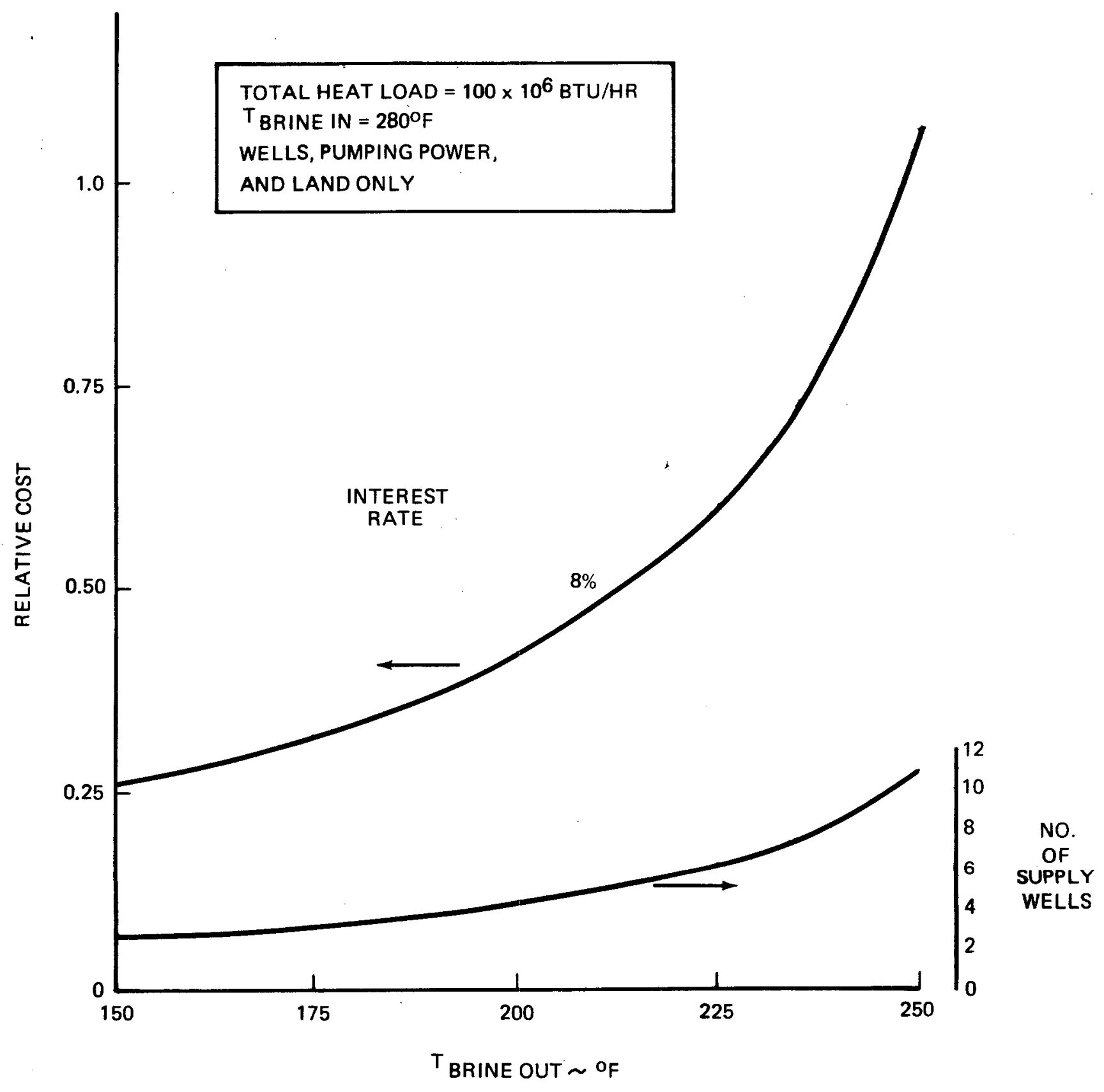

Figure 4-1 RELATIVE ENERGY COST VS BRINE RETURN TEMPERATURE 


\subsection{Geothermal Fluid Properties}

Physical and chemical properties of the geothermal fluid constraint the method by which the fluid may be used. The effects of these properties relate to the scaling tendency of the fluid, and potential corrosion by the non-condensible gases and brine salinity.

Analysis of the total dissolved solids in the Raft River KGRA indicates two different sources of geothermal water exist in deep wells. One of these is of a low salinity (approximately $1000 \mathrm{ppm}$ TDS) and one of a high salinity (about $6000 \mathrm{ppm}$ TDS). These waters are associated with local geographical conditions known as the Bridge fault and the narrows Structure (Ref. 3 ).

The fluid temperature of these two sources is also different. Bottom hole temperatures in deep wells vary by as much as $5^{\circ} \mathrm{F}$ for the same depth.

Non-condensible gases are present in the geothermal brine. Materials testing has shown there are trace amounts of hydrogen sulfide in the brines (Ref. 4). These are of sufficient quantity to cause corrosion problems with copper alloys. The final materials selection will take the fluid properties into consideration. 
Section 5

CONCEPTUAL DESIGN OF GEOTHERMAL

ENERGY GATHERING, TRANSFER,

AND DISPOSAL SYSTEM

A visit was made to the DOE Raft River site on September 19 and 20 to obtain design information on the geothermal resources and cost estimates for use of the geothermal resources at the crook and Glover properties. A summary of the geothermal resource characteristics is shown in Table 5-1.

5.1 Well Field Design

Discussions were held with geologist, hydrologists, and engineers of EG\&G concerning the Raft River area. No report is available which can supply the design conditions for the geothermal resources nor is there any general agreement on the extent of the resource.

There is major faulting in the Raft River area so that it is very difficult to predict the results from exploration drilling even if it is near an existing well. Multi-legged wells are not worth the additional expenditure just to increase the flow but can be used to improve a bad well. The flow increase is small for multi-legged wells, the cost is large, and there are chances of plugging one or the other legs due to obstructions from tailings. 
Table 5-1

Geothermal Resource

Design Bases

\section{Well Supply}

Temperature $=280^{\circ} \mathrm{F}$ (at surface)

Flow $=600 \mathrm{gpm} /$ well with $200 \mathrm{~kW}$ pumping power

Depth $=5000$ feet

Cost $=\$ 700,000$ to $\$ 900,000$ (1979\$)

(not including exploration cost)

Life = One new well every other year for 7 wells drilled.

Well Spacing - On a 1/4 Mile Square Grid

Non-condensible Gases - No $\mathrm{H}_{2} \mathrm{~S}$

Redundancy - 7 wells drilled for 5 producing wells (the 2 wells cannot be used for reinjection).

Scaling - Flashing of the brine should not be allowed. keep pressure above 100 psig.

Brine Disposal

Same quantity as obtained from the supply well must be reinjected.

One reinjection well per 2 supply wells into 1500 to 2500 aquifer.

Maximum reinjection pressure $=250 \mathrm{psig}$

No particles greater than 200 micron 
Estimates of well operating conditions also vary. Although the 5 MW Power Plant was designed for $290^{\circ} \mathrm{F}$, more recent data indicated an average temperature of 270 to $280^{\circ} \mathrm{F}$ (pumped and at the wellhead). Additional temperature loss in the pipelines can be expected. Flows of 500 to $600 \mathrm{gpm}$ per well are possible with pumping. Well depths are typically 5000 feet.

Although wells can be self flowing, pumping is recommended. A study for well pumping for the $5 \mathrm{MW}$ plant concluded there is an optimum operating pressure. Increasing the pump head increases the flow. Submersible pumps have been considered. Their use should be considered as developmental for this application. Line pumps can be used for pump depths of 800 feet and possible to 1200 to 1500 feet.

Well life is unknown. Although some wells have been in existence since 1975, insufficient information is available to project the operating life. Most analyses are based upon a maximum life of 5 years. Longer well flows are possible but at the expenses of increased pump setting depths and pump horsepower. Therefore, a recommendation of one new well every other year for every 5 to 7 production wells was made. 
5.2 Brine Gathering System

A supply well field layout using a square grid with a well spacing of $1 / 4$ to $1 / 2$ a mile is recommended. This is similar to oil fields. A general comment is that there is insufficient space on the Crook and Glover property to supply the ethanol production facility (based upon our preliminary estimate of five wells). Adjacent properties will be needed to supply the heat load requirement.

\subsection{Brine Disposal}

For brine reinjection, the fluid must be injected such that it does not contaminate the drinking water supply. Normally this might be into the same aquifer the brine is obtained from (at least about the same depth). More recent testing has shown an aquifer at 1500 to 2500 feet will accept reinjected flow readily (Ref. 5). Whether this can be used on a long term basis isn't known. It is estimated a reinjection pressure of 250 to $300 \mathrm{psi}$ is required at the end of five years. It is recommended there be one standby well for every two injection wells. One reinjection well per two supply wells is required for the shallow aquifer whereas a one-to-one ratio is required for the deeper aquifer.

The only present pretreatment for reinjection is 200 micron filtration. 5 micron filtration may be required. 
Section 6

ECONOMIC FACTORS

During the visit to Raft River, discussions were held with DOE personnel in order to obtain well drilling costs. In addition, discussions were held with the owner of the two properties under consideration - Gary Crook and Frank Glover.

\subsection{Geothermal Well Costs}

Well drilling costs were obtained from the DOE in a paper "Geothermal Well Drilling Estimates Based on Past Well costs". It is estimated that an annual inflation rate for wells is as high as 25\%. A 5000 foot well may cost up to $\$ 900,000$ (1979\$) not including exploration costs. A review of other DOE contracts showed exploration costs to range from $\$ 11,000$ (one case) to $\$ 100,000$ (two cases) (Ref.6).

\subsection{Crook's Property}

Mr. Crook provided three alternatives for the cost of his property. 1) An outright sale would cost $\$ 350,000$ (1and value of his property by other estimates is about $\$ 10,000)$. 2) A lease arrangement at $\$ 25,000 /$ year with him retaining the right to use of $150 \mathrm{gpm}$ of geothermal water at less than $180^{\circ} \mathrm{F}$ for his greenhouse. 3) Sell seven acres not including greenhouse but including geothermal rights at $\$ 150,000$. For this case he will also retain the rights to the use of $150 \mathrm{gpm}$ fluid flow. 
Mr. Crook does not have water rights. His land is located on a flood plain and would probably be a poor location for an ethanol plant.

\subsection{Glover's Prospect}

Frank Glover owns 160 acres at the Raft River site. He has hired an appraiser to determine the value of his property but has not yet obtained the report. When he does, he will send the results.

There are no producing water wells on his property. He has petitioned to drill a small exploratory well but as yet has not received approval.

\subsection{Electric Rates}

Electricity is obtained from the Raft River Elctrical Coop. A rate schedule was obtained and shows the power cost for industrial user to be less than $0.02 \$ / K W-\mathrm{Hr}$. The co-op indicated the rates will rise substantially in December. For installation cost of commercial size electrical loads, special rates may be obtained.

\subsection{Cooling Water}

The Raft River is a closed resource so that there can be no consumptive uses of water. This is interpreted to mean both geothermal and cooling water. Present water users may sell their water rights to other parties in 
the future. In addition, water rights are given only on realitively large areas of land. Thus the 10 acres of the Crook's property does not have water rights. However the 160 acres that his 10 acres is part of, has water rights. 


\section{REFERENCES}

1. Grain Motor Fuel Alcohol-Technical and Economic Assessment Study, HCP/J6639-01, Raphael Katzen Associates for U.S. DOE under Contract No. EJ-78-C-01-6639.

2. 1978 Agricultural Statistics, USDA, Economic, Statistics and Cooperative Service, Boise, Idaho, 1978.

3. C.A. Allen, R.E. Chaney, and R.E. McAtee, Geochemical Modeling at Raft River, Geothermal Resources Council, Transactions, Vol. 3, Sept. 1972 .

4. R.I. Miller, Corrosion of Copper-Base Alloys in a Geothermal Brine, AIME International Symposium on Oilfield and Geothermal Chemistry, Jan. 1979.

5. Discussions with R. Chappel of DOE, Idaho Operations Office and K. Jones of EG\&G, Idaho, Sept. 1979.

6. Discussions with C. Allen, D. Goldman, and S. Spencer of EG\&G, Idaho, Sept. 1979. 